\title{
Challenges of dairy cooperatives in the area of sales marketing
}

\author{
Izabela Konieczna \\ Jan Kochanowski University in Kielce
}

\section{Introduction}

Enterprises' activities are mainly focused on striving to create value for customers and on capturing this value. A trade offer that takes into account the perceived need for the best customers (possible to satisfy the market) significantly increases the probability of repeatable purchases ${ }^{1}$ and thus allows creating value for customers. Hence, companies do everything to reach different target groups. This is a challenge, however, because the expectations of various groups are different, so the other tools allow to reach their consciousness. Consequently, the actions of enterprises should be based on offering specific characteristics of the offer consistent with the preferences of the customers. Enterprises, however, in order to meet the customers' requirements should be aware of what features of the offer are most important for particular groups of customers they want to reach. Therefore, the aim of the article is to show how companies assess the importance of features of the offer in the area of sales marketing for various groups of customers. The implementation of the aim was based on the presentation and analysis of research results conducted with the help of an interview questionnaire among representatives of the management of cooperatives from two provinces: Świętokrzyskie and Małopolskie. The article endeavoured to find the answer to the following questions: 1. "Which features of the offer in the area of sales marketing are the most important for particular groups of customers?" and 2. "Is there a difference in the assessment of the validity of the features of the offer for individual groups of recipients among representatives of cooperatives from different provinces?".

1 P. Doyle, Value-Based Marketing: Marketing Strategies for Corporate Growth and Shareholder Value, John Wiley \& Sons, Chichester 2000, p. 71. 


\section{The issue of sales marketing}

Various features/elements of the offer that are valid for customers in the area of the sales marketing can be distinguished: the individualization of the offer; the price of the product; the range of pre-, peri-, and after-sales services; the price of such services; the payment terms; the crediting of purchases; the special sales conditions (discounts); the promotional prices; the novelty prices; advertisement; the loyalty programs; the consumer promotion (e.g. samples, coupons, contests, lotteries, gifts, etc.); public relations; publicity; the availability of information about the offer/product ${ }^{2}$. Therefore this is a huge challenge for companies to meet these expectations. However, companies do their best to make the customer buy their products and return.

\section{The individualization of the offer}

Individualization is the process of providing and developing products and services made in accordance with the individual preferences of a given client ${ }^{3}$. The company adapts certain elements of the offer to the characteristics and preferences of individual clients (individualizes or otherwise customizes them) so as to satisfy customers on the one hand, and keep costs at an acceptable level on the other ${ }^{4}$.

\section{The price of the product}

The price is a very sensitive and flexible element affecting the market behaviour of buyers ${ }^{5}$. Market-oriented pricing decisions are aimed at acquiring and retaining customers and gaining a privileged position on the market (acquiring part of the market, competition exclusion) ${ }^{6}$. Understanding and including in the price definition the value perceived by the customer may also lead to both higher sales and higher profit margins?.

2 I. Konieczna, Model biznesowy spółdzielni a model biznesowy przedsiębiorstw o innej formie organizacyjno-prawnej. Różnice, odrębność czynników sukcesu, Difin, Warszawa 2015, p. 99.

3 I.H. Gordon, Relacje z klientem. Marketing partnerski, Polskie Wydawnictwo Ekonomiczne, Warszawa 2001, p. 280.

4 M. Trojanowski, Marketing bezpośredni. Koncepcja - zarzqdzanie - instrumenty, Polskie Wydawnictwo Ekonomiczne, Warszawa 2010, p. 59.

5 J. Altkorn (ed.), Podstawy marketingu, Instytut Marketingu, Kraków 2004, p. 54.

6 M. Sierpińska, T. Jachna, Ocena przedsiębiorstwa wedtug standardów światowych, Wydawnictwo Naukowe PWN, Warszawa 2007, p. 230.

7 A. Codini, N. Saccani, A. Sicco, The relationship between customer value and pricing strategies, "Journal of Product \& Brand Management" 2012, no. 7, p. 539. 


\section{The range and the price of pre-sales, sales-related and after-sales services}

Customer value can be created at any stage of the purchasing process, i.e. in the pre-purchase phase, at the time and place of the transaction, and at the stage of customer experience after the purchase/sale transaction ${ }^{8}$. Pre-sales and sales-related services can be individually tailored to customer needs. Pre-sales services are those that rely on providing information to buyers about the product or the relevant advisory. The sales-related services include, among others, the ability to place orders over the phone, the Internet and favourable opening hours ${ }^{9}$. At this point, it is critical to hook the consumer in purchase intention and a delay period ${ }^{10}$. After-sales activities are those activities that happen after the purchase of the product and are devoted $^{11}$ to enable existing customers to quickly locate, contact and activate the supplier's resources that are needed in order to create satisfactory product-related services, answers to inquiries or solutions to problems ${ }^{12}$.

\section{The payment terms}

Payment has moved from a largely functional process, which has to be endured by the customer rather than enjoyed, to a vital part of a winning customer experience $^{13}$. Companies are trying to make payment so easy that a customer has no excuse not to complete the transaction, regardless of the channel they are in ${ }^{14}$. The company may use advance payments or prepayments, cash payments and trade credit in business contacts 15 .

$8 \quad$ A. Sagan, G. Plichta, Podejście środków-celów w ocenie regionalnego zróżnicowania wartości dla klienta w obszarze usług okołosprzedażowych, "Zeszyty Naukowe Uniwersytetu Szczecińskiego" 2010, no. 15, p. 88.

9 B. Pierański, Koncepcja jakości usługi handlowej, "Handel Wewnętrzny" 2011, no. 4, p. 4.

10 A. Sagan, G. Plichta, Podejście środków-celów..., p. 91.

11 P. Gaiardelli, N. Saccani, L. Songini, Performance measurement systems in after-sales service: An integrated framework, "International Journal of Business Performance Management" 2007, no. 9, p. 146.

12 S. Verstrepen, D. Deschoolmeester, R. Van den Berg, Servitization in the automotive sector: Creating value and competitive advantage through service after sales, [in:] Global Production Management: IFIP WG5.7 International Conference on Advances in Production Management Systems, September 6-10, Berlin 1999, p. 540.

13 The role of payments in the customer experience. How top retailers are navigating a changing payments landscape, Retail Week Reports, May 2017, p. 5.

14 Ibidem.

15 M. Sierpińska, Terminy płatności faktur w obrocie gospodarczym w Polsce na tle innych krajów Unii Europejskiej, "Studia Ekonomiczne" 2014, no. 198, 2nd part, p. 132. 


\section{The crediting of purchases}

The terms and forms of invoice payment, generally identified as payment terms, are among the basic instruments of the trade credit policy ${ }^{16}$. With their help, the company can modify customer behaviour and, consequently, influence the level of receivables. Payment terms of invoices must be adjusted to the level of credit risk of the customers to minimize the risk of overdue and uncollectible receivables and maximize sales ${ }^{17}$. Firms manipulate the respective terms in anticipation of capturing new business, in order to attract specific customers and achieve specific marketing goals ${ }^{18}$.

\section{The special sales conditions (discounts)}

The pattern of discount ordinarily can be divided into two types: general discount and performance discount. General discount is given for a short period and available to all types of customers, e.g. packaged discount (buy one get one free), stock clearance sale etc. Performance based discount is given mostly to loyal customers. This type of discount is dependent on the intake by the customers, e.g. quantity/volume based discount, discount on promptness of payment etc. ${ }^{19}$ Some of the smartly designed discount schemes could ignite the customers' desire for a particular product or a brand which otherwise are given a pass on account of various reasons ${ }^{20}$.

\section{The promotional prices}

Promotional prices are a way of differentiating the basic prices of the same products/ services. Promotional prices are lower than the basic prices. Their main task is to increase sales of given products/services in a short time by creating an atmosphere of extremely favourable shopping ${ }^{21}$. A price promotion can be produced by the face value of a coupon or the amount of a rebate. It provides a monetary gain, an incentive to encourage consumers to purchase the product. A price promotion can help customers simplify the decision process and reduce the transaction time or effort ${ }^{22}$.

16 Ibidem.

17 Ibidem.

18 H. Soni, N.H. Shah, C.K. Jaggi, Inventory models and trade credit: a review, "Control and Cybernetics" 2010, no. 3, p. 867.

19 C.P. Chattopadhyay, Discount and Treatment in Indirect Tax, "Tax Bulletin" 2018, vol. 8, p. 7.

20 Ibidem, p. 6.

21 A. Czubała et al., Marketing ustug, Oficyna Ekonomiczna, Kraków 2006, p. 191.

22 J.E. Lee, J.H. Chen Yu, Effects of price discount on consumers' perceptions of savings, quality, and value for apparel products: mediating effect of price discount affect, "Fashion and Textiles" 2018, no. 5, p. 4. 


\section{The novelty prices}

Enterprises are aware that many customers, wanting to buy an exclusive, fashionable product, are able to pay more to feel like a customer who is up-to-date with all the news. The price is the real, hard currency promise of what the new product will mean to the customer ${ }^{23}$. However, price-benefit analysis should begin early in the development cycle, when the market is first being probed, for it not only shows companies whether price barriers might make products unfeasible but can also guide their development by indicating which attributes customers are most willing to pay for ${ }^{24}$.

\section{Advertisement}

An advertisement is an attempt at creativity which influences the consumer's motive to buy a particular product and change or make the perception of the product in the mind of the consumers. An advertisement's appeal acts as a supplier to arouse the psychological motive of the consumer for buying ${ }^{25}$. The purpose of advertising is: creating needs (raising awareness of unmet needs and awakening the desire to possess), showing and reminding usability of a given product/service, shaping preferences and providing a set of arguments for choosing a given product/service, shaping a positive image of the sender of the advertisement ${ }^{26}$.

\section{The loyalty programs}

The loyalty program is a set of intended actions on the part of the manufacturer, aimed at binding the consumer with the brand for a long time ${ }^{27}$. Loyalty programs are not only a tool to increase the organization's loyal customers, but they are an opportunity to gather information about customer shopping habits and

23 B. Cohen, M. Neubert, Price-Setting Strategies for Product Innovations in the Medtech Industry, [in:] D. Vrontis, Y. Weber, E. Tsoukatos (eds), Global and national business theories and practice: bridging the past with the future, EuroMed Press, Rome 2017, p. 459.

24 M.V. Marn, E.V. Roegner, C.C. Zawada, Pricing new products, "The McKinsey Quarterly" 2003, no. 3 (July), p. 40-49, https://www.mckinsey.com/business-functions/marketing-and-sales /our-insights/pricing-new-products\# (dostęp: 6.01.2020).

25 S. Fatima, S. Lodhi, Impact of Advertisement on Buying Behaviours of the consumers: Study of Cosmetic Industry in Karachi City, "International Journal of Management Sciences and Business Research" 2015, vol. 4, issue 10, p. 126.

26 A. Czubata et al., Marketing..., p. 222.

27 H. Mruk (ed.), Komunikowanie się w marketingu, Polskie Towarzystwo Ekonomiczne, Warszawa 2004, p. 85. 
preferences ${ }^{28}$. A loyalty program may give a customer advanced access to new products, special sales coupons or free merchandise ${ }^{29}$. Introduction of loyalty programs is generally aimed, at achieving several key objectives, which fall into three main categories ${ }^{30}$ :

- maximization of value for customers, offering value that matches customers' expectations;

- enhancement of relationships that bond a customers with a firm;

- fulfilling loyalty program's commitments and promises.

\section{The customer promotion}

Sellers use promotion as an incentive instrument to promote in order to attract new customers, reward loyal customers and increase the rate of repurchase of occasional users ${ }^{31}$. Activities of sales promotion may be directed at consumers and business. Some of the forms of promotional activities which are intended for final users to stimulate immediate sales are: samples, coupons, discounts, premiums ${ }^{32}$, refunds, frequent-user incentives, point-of-purchase materials and demonstrations, consumer games, contests, sweepstakes ${ }^{33}$, and a variety of rewards for regular purchases $^{34}$. Trade sales promotion stimulate business to carry a producer's products and market these products more aggressively. These methods include buying allowances, buy-pack allowances, scan-back allowances, merchandise allowances, cooperative advertising, dealer listings, free merchandise, dealer loaders, premium or push money and sale contests ${ }^{35}$.

28 S.G. Magatef, E.F. Tomalieh, The Impact of Customer Loyalty Programs on Customer Retention, "International Journal of Business and Social Science" 2015, no. 8, p. 80.

29 Ibidem, p. 79.

30 K. Szczepańska, P. Gawron, Loyalty Programs Effectiveness, "Foundations of Management" 2011, no. 2, p. 95.

31 D. Alavuk, J. Jevtić, I. Petrevska, Sales Promotion as a Determining Factor in the Competitive Position of the Company, "Journal of Engineering Management and Competitiveness" 2015, no. 1, p. 51.

32 Ibidem.

33 O.C. Ferrell et al., Marketing Principles, Cengage Learning Australia Pty Limited, Melbourne 2015, p. 490.

34 D. Alavuk, J. Jevtić, I. Petrevska, Sales Promotion..., p. 51.

35 O.C. Ferrell et al., Marketing..., pp. 490-491. 


\section{Public relations}

Public relations is a management function of continuous and planned nature, thanks to which the organization acquires and maintains the understanding, sympathy and support of those with whom it is currently interested or may be interested in the future - by examining their opinion about the organization, in order to maximally align its goals and activities to them, to achieve through planned, wide dissemination of information better cooperation ${ }^{36}$ with its environment ${ }^{37}$ and to more effectively pursue its interests ${ }^{38}$. Public relations tools include: sponsorship, news (information about the company), conferences, trade shows, festivals, company identification means (advertising gadgets) ${ }^{39}$.

\section{Publicity}

Publicity includes activities aimed at attracting attention or making people aware of something by means of reliable and appropriate to send the means. Such activities usually include some specially planned event or other procedure intended to disrupt the continuity of everyday existence of people to whom publicity relates. Publicity can take the form of: message, comment, invitation, occasion, assurance, gesture, appeal, warning ${ }^{40}$. Publicity can build a trust from consumers to the company. Being public implies visibility, attention, prominence, identification, understanding, and openness ${ }^{41}$.

\section{The availability of information about the offer/product}

The availability of information about the offer/product is possible thanks to the marketing communications i.e. the means by which firms attempt to inform, persuade, and remind consumers - directly or indirectly - about the products and brands they sell. In a sense, marketing communications represent the voice of the

36 A. Szymańska, Public relations w systemie zintegrowanej komunikacji marketingowej, Unimex, Wroctaw 2004, p. 9.

37 J. Blythe, Komunikacja marketingowa, Polskie Wydawnictwo Ekonomiczne, Warszawa 2002, p. 139.

38 A. Szymańska, Public relations..., p. 9.

39 M. Sławińska (ed.), Kompendium wiedzy o handlu, Wydawnictwo Naukowe PWN, Warszawa 2008, p. 150.

40 A. Davis, Public relations, Polskie Wydawnictwo Ekonomiczne, Warszawa 2007, pp. 24-25.

41 A.R. Karema, The Influence of Advertising, Publicity, and Public Relation on Consumer Preference in Manado Quality Hotel, "Jurnal Berkala Ilmiah Efisiensi” 2016, no. 1, p. 14. 
company and its brands; they are a means by which the firm can establish a dialogue and build relationships with customers ${ }^{42}$. Marketing communication activities contribute to brand equity and drive sales in many ways: by creating brand awareness, forging brand image in consumers' memories, eliciting positive brand judgments or feelings, and strengthening consumer loyalty ${ }^{43}$.

As it was presented above, enterprises face a real challenge, because meeting and creating value for customers in the area of sales marketing is extremely difficult, because it consists of a number of elements, and customers are different and have different needs, hence enterprises can only reach them in a way that is acceptable and which appeals to the customer the most. Due to the fact that enterprises deal with various groups of customers, i.e. consumers and business, appropriate elements within sales marketing must also be adapted in order to meet customers' requirements, while maximizing value for the enterprise. Since these are different groups, other features of the offer will be suitable and will create value for the customer. Therefore, the range of elements that make up sales marketing must be wide, and the appropriate actions should be preceded by market research, so as to best tailor actions aimed at persuading customers to take advantage of the company's offer and bring benefits to both parties.

\section{Features/elements of the offer that are valid for customers in the area of the sales marketing - research results}

The research was conducted among cooperatives' executives who were asked to indicate the features of the offer in the sphere of sales marketing, which from their point of view are important for customers, and have an influence on clients' value. All dairy cooperatives from the Świętokrzyskie and Małopolskie provinces were asked to take part in the research, however, because of the tendency of the representatives of cooperatives to participate in the research, the research had been conducted on a sample of $41 \%$ of the dairy cooperatives from Świętokrzyskie and Małopolskie provinces using an interview questionnaire. As it was mentioned above, cooperatives as other enterprises face a real challenge, because meeting and creating value for customers in the area of sales marketing is extremely difficult, because it consists of a number of elements. However, to have an overview on this part of running the business the cooperatives' representatives were asked

42 P. Kotler, K.L. Keller, Marketing Management, Prentice Hall, New Jersey 2012, p. 476.

43 Ibidem, p. 478. 
to indicate features of the offer that, in their opinion, have an influence on different customers while taking into account a large number of indicated features. The interview results are shown in Table 1.

Table 1. The mean of the validity of features of the offer for customers in the area of the sales marketing in the assessment of dairy cooperatives from the Świętokrzyskie and Małopolskie provinces

\begin{tabular}{|c|c|c|c|c|c|c|c|c|c|c|}
\hline \multirow{2}{*}{\multicolumn{2}{|c|}{ Features/elements of the offer }} & \multirow{3}{*}{ 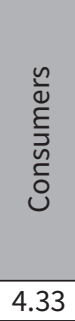 } & \multirow{3}{*}{ 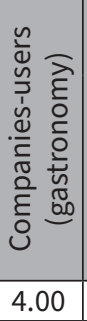 } & \multirow{3}{*}{ 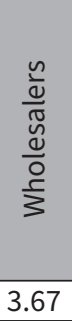 } & \multirow{3}{*}{ 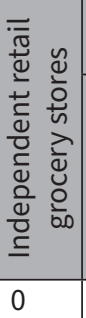 } & \multicolumn{2}{|c|}{$\begin{array}{l}\text { Retail } \\
\text { chains }\end{array}$} & \multirow{3}{*}{ 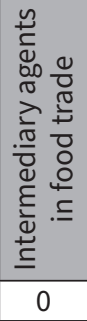 } & \multirow{3}{*}{ 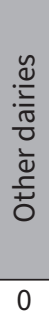 } & \multirow{3}{*}{ 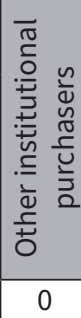 } \\
\hline & & & & & & \multirow{2}{*}{ 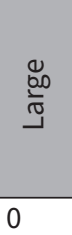 } & \multirow{2}{*}{$\begin{array}{l}\text { तु } \\
\text { O } \\
3.67\end{array}$} & & & \\
\hline \multirow{2}{*}{$\begin{array}{l}\text { The individualization } \\
\text { of the offer }\end{array}$} & $\mathrm{SP}$ & & & & & & & & & \\
\hline & MP & 3.25 & 3.75 & 3.75 & 4.00 & 3.00 & 4.25 & 0 & 0 & 0 \\
\hline \multirow[t]{2}{*}{ The price of the product } & SP & 3.67 & 4.00 & 4.67 & 0 & 0 & 4.33 & 0 & 0 & 0 \\
\hline & MP & 4.25 & 4.00 & 4.25 & 4.00 & 5.00 & 4.25 & 0 & 0 & 0 \\
\hline \multirow{2}{*}{$\begin{array}{l}\text { The range of pre-sales, } \\
\text { sales-related, and after- } \\
\text { sales services }\end{array}$} & SP & 4.33 & 4.00 & 3.67 & 0 & 0 & 4.67 & 0 & 0 & 0 \\
\hline & MP & 4.25 & 4.50 & 4.00 & 4.00 & 4.00 & 3.50 & 0 & 0 & 0 \\
\hline \multirow{2}{*}{$\begin{array}{l}\text { The price of pre-sales, } \\
\text { sales-related, and after- } \\
\text { sales services }\end{array}$} & SP & 4.00 & 4.50 & 4.00 & 0 & 0 & 4.33 & 0 & 0 & 0 \\
\hline & MP & 4.50 & 4.50 & 4.25 & 4.00 & 5.00 & 3.75 & 0 & 0 & 0 \\
\hline \multirow[t]{2}{*}{ The payment terms } & $\mathrm{SP}$ & 4.67 & 3.50 & 4.00 & 0 & 0 & 3.67 & 0 & 0 & 0 \\
\hline & MP & 4.00 & 3.50 & 4.25 & 3.00 & 4.00 & 4.50 & 0 & 0 & 0 \\
\hline \multirow{2}{*}{$\begin{array}{l}\text { The crediting } \\
\text { of purchases }\end{array}$} & $\mathrm{SP}$ & 4.00 & 4.50 & 3.67 & 0 & 0 & 4.33 & 0 & 0 & 0 \\
\hline & MP & 3.75 & 3.50 & 4.75 & 4.00 & 3.00 & 4.50 & 0 & 0 & 0 \\
\hline \multirow{2}{*}{$\begin{array}{l}\text { The special sales } \\
\text { conditions (discounts) }\end{array}$} & SP & 3.67 & 4.00 & 4.00 & 0 & 0 & 4.00 & 0 & 0 & 0 \\
\hline & MP & 3.75 & 3.75 & 4.00 & 4.00 & 4.00 & 4.25 & 0 & 0 & 0 \\
\hline \multirow[t]{2}{*}{ The promotional prices } & $\mathrm{SP}$ & 4.33 & 5.00 & 4.00 & 0 & 0 & 3.67 & 0 & 0 & 0 \\
\hline & MP & 3.75 & 3.25 & 3.50 & 5.00 & 5.00 & 3.75 & 0 & 0 & 0 \\
\hline \multirow[t]{2}{*}{ The novelty prices } & $\mathrm{SP}$ & 4.00 & 4.00 & 4.00 & 0 & 0 & 3.67 & 0 & 0 & 0 \\
\hline & MP & 4.25 & 4.00 & 4.00 & 4.00 & 2.00 & 3.75 & 0 & 0 & 0 \\
\hline \multirow[t]{2}{*}{ Advertisement } & SP & 3.67 & 4.00 & 4.00 & 0 & 0 & 3.67 & 0 & 0 & 0 \\
\hline & MP & 3.75 & 3.50 & 3.50 & 4.00 & 3.00 & 4.50 & 0 & 0 & 0 \\
\hline \multirow[t]{2}{*}{ The loyalty programs } & $\mathrm{SP}$ & 4.33 & 3.50 & 4.33 & 0 & 0 & 4.00 & 0 & 0 & 0 \\
\hline & MP & 4.00 & 4.75 & 4.25 & 4.00 & 4.00 & 3.75 & 0 & 0 & 0 \\
\hline \multirow{2}{*}{$\begin{array}{l}\text { The customer } \\
\text { promotion (e.g. } \\
\text { samples, coupons, } \\
\text { contests, lotteries, gifts, } \\
\text { etc.) }\end{array}$} & $\mathrm{SP}$ & 4.33 & 3.00 & 3.67 & 0 & 0 & 4.00 & 0 & 0 & 0 \\
\hline & MP & 4.00 & 4.50 & 4.50 & 4.00 & 4.00 & 4.75 & 0 & 0 & 0 \\
\hline \multirow[t]{2}{*}{ Public relations } & $\mathrm{SP}$ & 2.67 & 3.50 & 3.67 & 0 & 0 & 3.50 & 0 & 0 & 0 \\
\hline & MP & 3.25 & 4.67 & 4.00 & 4.00 & 4.00 & 4.00 & 0 & 0 & 0 \\
\hline
\end{tabular}


Table 1 (continued)

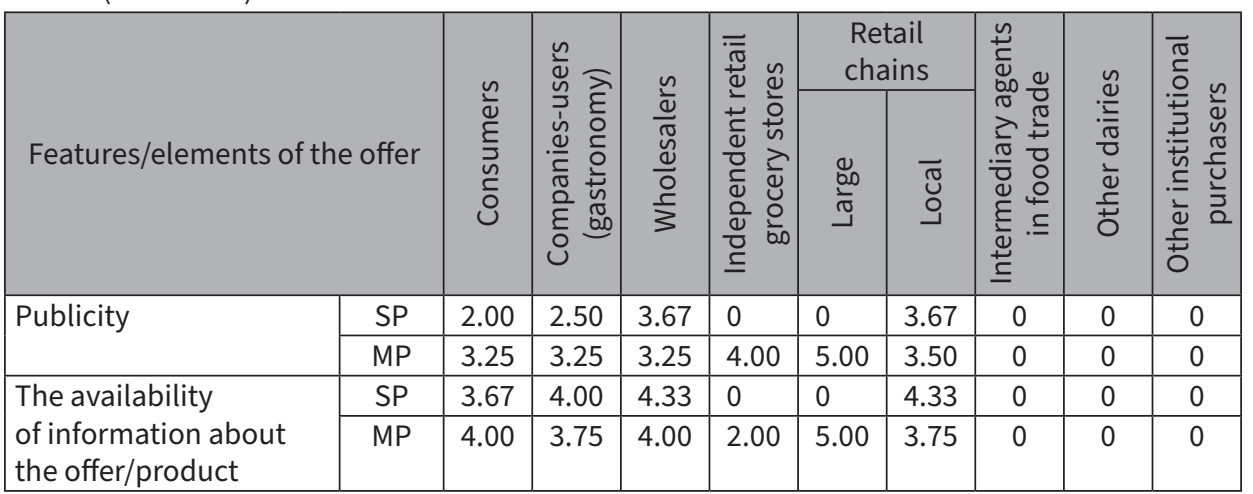

SP - Świętokrzyskie Province

MP - Małopolskie Province

Scale: 1-5, where 5 - extremely important, 4 - very important, 3 - quite important, 2 - little important, 1 - completely unimportant, 0 - not applicable.

Source: compiled by author and I. Konieczna, The Validity of the Features of the Offer for Clients in the Sphere of Sales Marketing - the Assessment of Dairy Cooperatives from Świętokrzyskie Province, [in:] Z. Primorac, C. Bussoli, N. Recker (eds), Economic and Social Development (Book of Proceedings), 16th International Scientific Conference on Economic and Social Development - Legal Challenges of Modern World, Varazdin Development and Entrepreneurship Agency, University of Split, University North, Split 2016, pp. 820-821.

Taking into account the respondents' answers shown in Table 1, it is clear that cooperatives from both provinces have such customers as consumers, companiesusers (gastronomy), wholesalers and local retail chains. Additionally, among cooperatives from the Małopolskie Province are such customers as independent retail grocery stores and large retail chains. Besides, all analyzed cooperatives do not have such customers as intermediary agents in food trade, other dairies, and other institutional purchasers.

When analyzing table 1 it is clear that:

- The individualization of the offer is very important for companies - users, wholesalers and local retail chains in the opinion of cooperatives from the Świętokrzyskie and Małopolskie provinces. It is also very important for independent retail grocery stores according to cooperatives from the Małopolskie Province (MP) and for consumers of products of dairy cooperatives from the Świętokrzyskie Province (SP). As was claimed by cooperatives from MP this feature is also quite important for consumers and large retail chains.

- The price of the product is extremely important for large retail chains, and very important for local retail chains according to cooperatives from MP. It is also very important for consumers, companies - users, wholesalers, and independent retail grocery stores in the opinion of cooperatives from both analyzed provinces. 
- The range of pre-sales, sales-related, and after-sales services is extremely important for local retail chains according to cooperatives from SP and for companies-users according to cooperatives from MP. This feature is very important for consumers and wholesalers in the opinion of cooperatives from both provinces. It is also important for independent retail grocery stores and large retail chains from the point of view of cooperatives from MP and for companies-users from the point of view of cooperatives from SP.

- The price of pre-sales, sales-related, and after-sales services is extremely important for large retail chains, consumers, and companies-users in the opinion of cooperatives from MP, and for companies-users in the opinion of cooperatives from SP. This feature is very important for wholesalers and local retail chains from the point of view of cooperatives from both provinces. Additionally, it is also very important for independent retail grocery stores according to cooperatives from MP, and for consumers according to cooperatives from SP.

- The payment terms are extremely important for consumers of products of dairy cooperatives from SP, and for local retail chains according to cooperatives from MP. They are very important for companies-users and wholesalers in the opinion of cooperatives from both provinces. This feature is also very important for consumers and large retail chains from the point of view of cooperatives from MP, and for local retail chains from the point of view of cooperatives from SP. According to cooperatives from MP this feature is quite important for independent retail grocery stores.

- The crediting of purchases is extremely important for wholesalers and local retail chains in the opinion of cooperatives from MP, and for companies-users in the opinion of cooperatives from SP. It is very important for consumers of products of dairy cooperatives from both provinces. This feature is very important for companies-users and independent retail grocery stores according to cooperatives from MP, and for wholesalers and local retail chains according to cooperatives from SP. From the point of view of cooperatives from MP this feature is quite important for large retail chains.

- The special sales conditions are very important for consumers, companies - users, wholesalers, and local retail chains in the opinion of cooperatives from both provinces. This feature is also very important for independent retail grocery stores and large retail chains according to cooperatives from MP.

- The promotional prices are extremely important for companies-users from the point of view of cooperatives from SP and for independent retail grocery stores and large retail chains according to cooperatives from MP. This feature is very important for consumers, wholesalers, and local retail chains 
from the point of view of cooperatives from both provinces. In the same time cooperatives from MP claim that this feature is quite important for companies - users.

- The novelty prices are very important for consumers, companies - users, wholesalers, and local retail chains form the point of view of provinces from both provinces, and for independent retail grocery stores according to cooperatives from MP. In the same time cooperatives from MP claim that this feature is little important for large retail chains.

- Advertisement is very important for consumers, companies - users, and wholesalers in the opinion of cooperatives from both provinces, for independent retail grocery stores according to cooperatives from MP, and for local retail chains from the point of view of cooperatives SP. As claim cooperatives from MP this feature is quite important for large retail chains.

- The loyalty programs are extremely important for companies-users from the point of view of cooperatives from MP. It is very important for consumers, wholesalers, and local retail chains in the opinion of cooperatives from both provinces. It is also very important for independent retail grocery stores and large retail chains according to cooperatives from cooperatives from MP.

- The customer promotion is extremely important for companies-users and local retail chains from the point of view of cooperatives from MP. It is very important for consumers, and wholesalers in the opinion of cooperatives from both provinces. In the same time it is very important for local retail chains according to cooperatives from SP, and for independent retail grocery stores and large retail chains according to cooperatives from MP. This feature is quite important for companies-users from the point of view of cooperatives from SP.

- Public relations is extremely important for companies-users from the point of view of cooperatives from MP. This feature is very important for wholesalers and local retail chains according to cooperatives from both provinces, for independent retail grocery stores, and large retail chains according to cooperatives from MP. It is also very important for companies-users from the point of view of cooperatives from SP. According to cooperatives from both provinces this feature is quite important for consumers.

- Publicity is extremely important for large retail chains according to cooperatives from MP. This feature is very important for local retail chains from the point of view of cooperatives from both provinces, for wholesalers according to cooperatives from SP, and for independent retail grocery stores according to cooperatives from MP. It is quite important for companies-users in the opinion of cooperatives from both provinces, and for consumers and 
wholesalers from the point of view of cooperatives from MP. In the same time this feature is little important according to cooperatives from SP.

- The availability of information about the offer/product is extremely important for large retail chains in the opinion of cooperatives from MP. It is very important for consumers, companies-users, wholesalers and local retail chains from the point of view of cooperatives from both provinces. This feature is also little important for independent retail grocery stores according to cooperatives from MP.

\section{Conclusions}

Enterprises face challenges including adapting sales marketing tools to the right clients so as to maximize value for both customers and themselves. Hence, companies must be aware of what element of the offer goes most to a specific group of customers. The analysis of the conducted research showed that cooperatives know what features of the offer in the area of sales marketing are important for their customers. It can also be seen that these features differ depending on the province where the cooperatives come from. Considering the average rating for all customers it occurred that, in accordance with the opinion of the cooperatives from the Małopolskie Province the highest ranked are: the price of pre-sales, salesrelated, and after-sales services (average rating 4.33), the price of the product and the customer promotion (average rating 4.29), while the lowest are the individualization of the offer and the novelty prices (average rating 3.67). On the other hand, while taking into account the opinion of cooperatives from the Świętokrzyskie Province the highest ranked are the promotional prices (average rating 4.29) and the price of pre-sales, sales-related, and after-sales services (average rating 4.21), and that lowest are publicity (average rating 2.96) and public relations (average rating 3.34). At the same time, the results of the research showed that the group of customers for whom, on average, the highest importance of the features of the offer was rated are local retail chains. In this case, among the assessment of dairy cooperatives from both provinces is compliance.

A limitation of the research is the range. It results from the fact that only cooperatives from two provinces were researched here. In addition, the research results are limited to one organizational and legal form of enterprises, i.e. cooperatives. It seems reasonable that further research should be at least nationwide and cover various organizational and legal forms of enterprises. 
References

Alavuk D., Jevtić J., Petrevska I., Sales Promotion as a Determining Factor in the Competitive Position of the Company, "Journal of Engineering Management and Competitiveness" 2015, no. 1 , pp. 50-54.

Altkorn J. (ed.), Podstawy marketingu, Instytut Marketingu, Kraków 2004.

Blythe J., Komunikacja marketingowa, Polskie Wydawnictwo Ekonomiczne, Warszawa 2002.

Chattopadhyay C.P., Discount and Treatment in Indirect Tax, "Tax Bulletin" 2018, vol. 8, pp. 7-9.

Codini A., Saccani N., Sicco A., The relationship between customer value and pricing strategies, "Journal of Product \& Brand Management" 2012, no. 7, pp. 538-546.

Cohen B., Neubert M., Price-Setting Strategies for Product Innovations in the Medtech Industry, [in:] D. Vrontis, Y. Weber, E. Tsoukatos (eds), Global and national business theories and practice: bridging the past with the future, EuroMed Press, Rome 2017, pp. 459-474.

Czubała A., Jonas A., Smoleń T., Wiktor J., Marketing usług, Oficyna Ekonomiczna, Kraków 2006.

Davis A., Public relations, Polskie Wydawnictwo Ekonomiczne, Warszawa 2007.

Doyle P., Value-Based Marketing: Marketing Strategies for Corporate Growth and Shareholder Value, John Wiley \& Sons, Chichester 2000.

Fatima S., Lodhi S., Impact of Advertisement on Buying Behaviours of the consumers: Study of Cosmetic Industry in Karachi City, "International Journal of Management Sciences and Business Research" 2015, vol. 4, issue 10, pp. 125-137.

Ferrell O.C., Niininen O., Lukas B., Schembri S., Pride W.M., Marketing Principles, Cengage Learning Australia Pty Limited, Melbourne 2015.

Gaiardelli P., Saccani N., Songini L., Performance measurement systems in after-sales service: An integrated framework, "International Journal of Business Performance Management" 2007, no. 9, pp. 145-171.

Gordon I.H., Relacje z klientem. Marketing partnerski, Polskie Wydawnictwo Ekonomiczne, Warszawa 2001.

Karema A.R., The Influence of Advertising, Publicity, and Public Relation on Consumer Preference in Manado Quality Hotel, "Jurnal Berkala Ilmiah Efisiensi" 2016, no. 1, pp. 12-20.

Konieczna I., Model biznesowy spółdzielni a model biznesowy przedsiębiorstw o innej formie organizacyjno-prawnej. Różnice, odrębność czynników sukcesu, Difin, Warszawa 2015.

Konieczna I., The Validity of the Features of the Offer for Clients in the Sphere of Sales Marketing - the Assessment of Dairy Cooperatives from Świętokrzyskie Province, [in:] Z. Primorac, C. Bussoli, N. Recker (eds), Economic and Social Development (Book of Proceedings), 16th International Scientific Conference on Economic and Social Development - Legal Challenges of Modern World, Varazdin Development and Entrepreneurship Agency, University of Split, University North, Split 2016, pp. 817-826.

Kotler P., Keller K.L., Marketing Management, Prentice Hall, New Jersey 2012.

Lee J.E., Chen Yu J.H., Effects of price discount on consumers' perceptions of savings, quality, and value for apparel products: mediating effect of price discount affect, "Fashion and Textiles" 2018, no. 5, pp. 1-21.

Magatef S.G., Tomalieh E.F., The Impact of Customer Loyalty Programs on Customer Retention, "International Journal of Business and Social Science" 2015, no. 8, pp. 78-93.

Marn M.V., Roegner E.V., Zawada C.C., Pricing new products, "The McKinsey Quarterly" 2003, no. 3 (July), pp. 40-49, https://www.mckinsey.com/business-functions/marketing-and-sa les/our-insights/pricing-new-products\# (dostęp: 6.01.2020).

Mruk H. (ed.), Komunikowanie się w marketingu, Polskie Towarzystwo Ekonomiczne, Warszawa 2004.

Pierański B., Koncepcja jakości usługi handlowej, "Handel Wewnętrzny” 2011, no. 4, pp. 3-10. 
Sagan A., Plichta G., Podejście środków-celów w ocenie regionalnego zróżnicowania wartości dla klienta w obszarze ustug okołosprzedażowych, "Zeszyty Naukowe Uniwersytetu Szczecińskiego" 2010, no. 15, pp. 87-98.

Sierpińska M., Terminy płatności faktur w obrocie gospodarczym w Polsce na tle innych krajów Unii Europejskiej, "Studia Ekonomiczne" 2014, no. 198, 2nd part, pp. 131-140.

Sierpińska M., Jachna T., Ocena przedsiębiorstwa wedtug standardów światowych, Wydawnictwo Naukowe PWN, Warszawa 2007.

Stawińska M. (ed.), Kompendium wiedzy o handlu, Wydawnictwo Naukowe PWN, Warszawa 2008.

Soni H., Shah N.H., Jaggi C.K., Inventory models and trade credit: a review, "Control and Cybernetics" 2010, no. 3, pp. 867-882.

Szczepańska K., Gawron P., Loyalty Programs Effectiveness, "Foundations of Management" 2011, no. 2, pp. 89-102.

Szymańska A., Public relations w systemie zintegrowanej komunikacji marketingowej, Unimex, Wroctaw 2004.

The role of payments in the customer experience. How top retailers are navigating a changing payments landscape, Retail Week Reports, May 2017.

Trojanowski M., Marketing bezpośredni. Koncepcja - zarządzanie - instrumenty, Polskie Wydawnictwo Ekonomiczne, Warszawa 2010.

Verstrepen S., Deschoolmeester D., Van den Berg R., Servitization in the automotive sector: Creating value and competitive advantage through service after sales, [in:] Global Production Management: IFIP WG5.7 International Conference on Advances in Production Management Systems, September 6-10, Berlin 1999, pp. 538-545.

\section{Abstract}

The article sets itself the goal of presenting how cooperatives assess the importance of features of the offer in the area of sales marketing for various groups of customers. The implementation of the goal was based on the presentation and analysis of the results of research conducted among the management of cooperatives from two provinces: Świętokrzyskie and Małopolskie using an interview questionnaire. Research results show that cooperatives from both provinces assessed the importance of features of the offer differently, but their opinions are similar in terms of the group of customers for which the importance of the features of the offer in the area of sales marketing was rated the highest.

Keywords: sales marketing, features of the offer, cooperatives 